\title{
On the Present Situation and Suggestions of Institutional Education in Universities
}

\author{
Xiangyu Leng 1,2 \\ ${ }^{1}$ School of Marxism, Southwest Jiaotong University, Chengdu, China \\ ${ }^{2}$ College of Chemistry and Chemical Engineering, Xinyang Normal University, Xinyang, China \\ Email: lengyinzhen@163.com
}

How to cite this paper: Leng, X.Y. (2017) On the Present Situation and Suggestions of Institutional Education in Universities. Open Journal of Social Sciences, 5, 241-247. https://doi.org/10.4236/jss.2017.510021

Received: August 23, 2017

Accepted: October 28, 2017

Published: October 31, 2017

Copyright (c) 2017 by author and Scientific Research Publishing Inc. This work is licensed under the Creative Commons Attribution International License (CC BY 4.0).

http://creativecommons.org/licenses/by/4.0/

\begin{abstract}
University institutions are among the resources of civic education; institutional education is to develop all-round people with good rules and regulations; university institutions haven't achieved their educational effects in the civic education; this research explores the effect of the institution in university, and the reasons for the poor effect of institution education; we have to strengthen the institutional construction of universities to achieve the goal of civic education through the following routes: One is to re-examine the virtue of university institution and to examine whether the university institution conforms to the rule of law; the other one is to ensure strict implementation of university institution. Only in this way, can university institutional education enhance the civic consciousness of college students.
\end{abstract}

\section{Keywords}

Civic Education, Institutional Education, Suggestions

\section{Introduction}

The fundamental mission of Chinese education is to strengthen moral education and cultivate talents. In order to realize the goal of cultivating qualified citizens of society, universities must use the important resource of institutions. The essence of civic education requires that universities must put various rules and regulations into practice.

\section{The Connotations of Institutional Education}

An institution is a system of mandatory rules that adjust the relations between individuals and between people and society or stipulate the acts of doers in particular social life. It contains certain value pursuit, since an institution plays an 
important guiding role in people's selection on valuation and value orientation. As a measurement criterion, it can restrain people's behaviors, and have a correction effect on people's pursuit of value, so as to promote and develop personal abilities. The system of institutional norms in terms of civic education and management constructed by universities should be coordinated with laws and regulations to help students grow up comprehensively. Universities adhere to integrating management and education to form a good educational atmosphere and work pattern of "education, management and service", in order to effectively guide students' ideological conducts. Therefore, it is the most important link of civic education to carry out educational work through institutional practice.

"Institution" mentioned in this paper refers to the general term of various management rules and regulations related to students in colleges and universities, which is the code of conducts to coordinate the relationship between universities, teachers and students and regulate students' learning and living behaviors. It plays the role of behavior regulation and value orientation in the process of their growth, which helps them to develop good qualities, thus forming moral personality with harmonious virtue. Institutional arrangement and design are the materialization and embodiment of certain ethical ideas, and also an ethical spirit which is structured and programmed. Institutions should regulate and restrain the behaviors of university students as well as influence their value orientation and moral character. Institutional education is to take the rules and regulations of universities as the resources, carriers and means to educate students, cultivating all-round talents with good institutions.

\section{The Plight of Institutional Education in the Civic Education}

The civic education is to transmit Chinese mainstream values and the norms to the university students and implement them in the individuals. Cultivating university students' consciousness of rule of law, and developing the habit of following the institution. Institutional management is an important and effective means for education management in colleges and universities. It has a unique effect on the smooth running of education management and helping students develop good character. The core value of university institutions is to educate people. However, the problems of institutions existing in practice affect the effect of educating people and play a counteracting role on the civic education.

In recent years, there have been more and more anomie behaviors among college students, even with increasing trend of illegal behaviors. For instance, university students violate college rules and cheating. Individual students only enjoy the rights and not fulfill their obligations. From a certain perspective, there is something wrong with the institutions, which precisely results in that the goal of educating people has not been achieved. The anomie phenomenon has a generalization tendency in the individuals of university students. Therefore, it is difficult to achieve practical effects in terms of moral and disciplinary education in a short time. When university students' anomie behaviors appear in large 
quantities or occur extensively, the key reason of the problem is that serious injustice or defects occur in social structure and institutional system, which causes them unable to play an effective role in restraining bad behaviors of individuals. Thus, lots of anomie conducts beyond the institutional norms appear among the college students. Rights and obligations, Discipline and Punishment are still not clear enough. University students have no fear of the regime. Therefore, institutional construction has become the fundamental approach of educating people.

In terms of institutional construction, institutional education should consider the following aspects: how to reflect the fundamental value of educating people; how to embody the subjectivity of civic education; how to pay attention to the needs of students' moral development in implementation; how to avoid the utilitarianism and pragmatism of institutional objectives and contents to be an issue of the aim of institutional practice, etc.

\section{Reasons for the Poor Effect of Institutional Education}

When people are under the system that one can benefit from doing evil, it is futile to persuade people to do good. When college students find out that there are problems with a particular system or norm involving their personal interests, they will usually change their cognition, try to join the group and share the benefits from such institutional problems.

\subsection{Value Misplacement of the Institutions and Partial Absence of Normative Subject}

The civic education focuses on students' ideological morality, and attaches more importance to the management function of institutions in practice. In reality, giving priority to maintain a stable order and regulate students' behaviors, institutions are easy to be limited to management rules for students' behaviors, emphasizing students' obedience. Thus, education and management become two uncoordinated skins, as the proverb goes' say one thing and do another', which consequently results in the value misplacement of education. The object of institutional norms should be various subjects of civic education, including department organizations, teachers and students. However, the object of current institutional norms is mainly college students. The situation where institutions position the organizations or teachers outside the system of educating people causes that educational work is difficult to be carried out in full swing, and disharmony even occurs in ideological education because of some divergences. If institutions pursue utilitarianism in the reality, belittling the educational value of institutions consciously or unconsciously, it will be difficult to achieve the goal and effect of educating people.

\subsection{Design Defects of Some Rules and Regulations}

In addition to rights and obligations as well as the content of rewards and punishments, rules and regulations of universities should also contain worldly ideals, moral quality, scientific attitude and other things. In terms of design phi- 
losophy, universities focus on management to maintain teaching order. In that case, educating people is not the focus of the rules and regulations, so educational function is partially defective. Many schools adopt the method of target quantitative assessment, which has specific standards for departments, teachers or students. All the subjects are busy completing their own indicators to cope with the assessment, so they ignore the "real" ideological education. When this idea is spread to students' thoughts and behaviors, they also center on assessment indicators and counterfeit in order to meet the requirements. Not subject to the rule of law considerations and scrutiny.

\subsection{The Implementation Environment of Institutions Needs to Be Optimized}

Some bad practices on campus, such as counterfeiting and giving dinners or gifts, are due to the influence by unhealthy practices and evil phenomena in society. One of the reasons is that people can't obey the institution in society, and thus the existence of the rules and regulations has little effect on the study and life of teachers and students. When people have weak awareness of observing disciplines and obeying laws, bad practices will be permeate the whole surroundings. Phenomena such as students' incorrect cognition of the law and discipline as well as violations of the law and discipline indicate that the implementation environment of the rules and regulations has been ignored. If there are conflicts between education and management, including students' self-education management for a long time, the status will be formed where students failed examinations, teachers care little about students' study and schools make no investigation. Once there are violations of discipline, unhealthy practices and evil phenomena will occupy the high ground of thoughts and behaviors.

\section{Suggestions for Carrying out Institutional Education in Universities}

"Good institutions can make bad people unable to run amuck arbitrarily, while bad institutions can make good people unable to do good, and even go to the opposite side" [1]. In terms of institutional construction, implementation of institutions is the key to realizing the goal of "cultivating qualified citizens of society".

\subsection{Focusing on Moral Construction}

Good institutions are able to provide the environment of developing and coming into play for the qualities that are beneficial to individual improvement and conducive to other people's happiness. Meanwhile, they can effectively control bad qualities and behaviors such as seeking benefits at the expense of others. Just institutions tend to develop just virtues, so institutions must be examined in morality. Only by providing just institutions for teachers and students with good guaranty mode leading them to develop in the direction of observing law and discipline, will widespread state of virtue appear on campus, whereby people on 
campus can be in transition to the status of possessing the virtue with graceful soul [2]. Whenever making rules and regulations, universities have to take "cultivating qualified citizens of society" as the goal. Various interest-related subjects should be encouraged to participate in the discussion. In particular, universities should listen to the will of the students, making in-depth discussions through them on the rules and regulations to be introduced, and lay stress on developing students' good behaviors. The foundation of rules and regulations is the common "agreement". In order to achieve the educational and guiding effects, teachers and students must participate jointly, combine the means of management and self-management, and bring the subjective initiative into play. This is also the form and process of civic education. The significance is much greater than that of the rules and regulations formulated and issued hastily.

\subsection{Focusing on the Construction of Ruling by Law}

Institutional construction of universities must be consistent with laws and regulations, and cannot be beyond the provisions of laws and regulations. The key to the rationality of institutions and the realization of educational value is "the supremacy of law". Whenever institutions are in conflict with laws and educational regulations, adjustment must be made in a timely manner. The construction of ruling by law for institutions should abide by "justice". The practice subjects of the institutions are university administrators, teachers and students, so it is necessary for them to participate in the process of concrete practice. Their communication and coordination is an important part of institutional practice. Universities should insist on democracy and set channels for students to express their opinions and for the school to give feedback. Students are encouraged to participate in school management reasonably and orderly, which will promote them to play the subjective role properly. At the same time, universities should attach great importance to the opinions of legal workers, and refer to the cases encountered in the judicial field. In-depth discussion on the specific content should be conducted to make it consistent with laws and regulations, whereby the problems of ruling by law resulted from institutional loopholes or defects will be reduced to a minimum.

\subsection{Implementing Rules and Regulations Strictly}

"A step of practical action is more important than a dozen of programs" [3]. Rules and regulations have the same constraining force for both teachers and students. Universities should maintain various rules and regulations strictly, and improve various criteria for evaluation and assessment. Teachers should take the lead in implementing the rules and regulations, consciously avoid academic cheating and fraud, and direct students to complete studies as their guides. Students should observe the rules and regulations conscientiously, act in accordance with the institutions, and raise the awareness of ruling by law. Student management should be in line with the spirit of "learn from past mistakes to avoid fu- 
ture ones and cure the sickness to save the patient". The rules for reward and punishment should be kept strictly among students. "For those who have made mistakes, some need to be properly punished. However, help rather than punishment should be emphasized. We should enthusiastically help them to correct their mistakes and improve themselves" [4]. Strictly performing the institutions is to promote teachers and students to understand, grasp and apply them in a better way. This is also an understanding and practice of ruling by law in essence, which helps people to improve the awareness of ruling by law and develop behavioral habits.

\subsection{Shaping the Environment of Ruling by Law}

In order to enhance the effectiveness of institutional education, different strategies should be adopted to shape the practice environment of ruling by law and create the cultural atmosphere of ruling by law. The environment of ruling by law on campus is that "everyone is equal before laws and institutions" [5]. College students have a certain sense of democracy, ruling by law and equality, and faculty members should be fine examples of observing law and discipline. As the saying goes, "if the ruler acts properly, the common people will obey him without being ordered to". Students are more concerned about how the faculty members do it. Various rules and regulations shall be implemented. In particular, the consistency of education and management shall be realized. The cultural atmosphere of self-discipline should be advocated and all should do it with the spirit of "starting from me" in a persistent way, whereby a good school climate will be formed. Only when all the faculty members and students observe law and discipline, practice the institutions with their words and deeds, play the role of examples, and create a stable, orderly and harmonious environment, can the purpose of education be achieved.

\section{Conclusion}

University institution must have explicit stipulation on the rights and obligations of students and accord with the rule of law of the state. College students must strictly abide by the rights and obligations stipulated by the institution. Only by executing the institution strictly and improving the operating environment constantly, can the authority of the institution be established, whereby all the students can set up belief in the rule of law.

\section{References}

[1] Deng, X.P. (1994) Selected Works of Deng Xiaoping (Volume 2). People's Publishing House, Beijing, 333.

[2] Wang, Y.R. (2004) Institutional Arrangements for Economic Ethics Construction. Guangming Daily, 7 December 2004.

[3] Marx (1971) Karl Marx and Frederick Engels (Volume 35). People's Publishing House, Beijing, 13. 
[4] Deng, X.P. (1994) Selected Works of Deng Xiaoping (Volume 2). People's Publishing House, Beijing, 51.

[5] Deng, X.P. (1994) Selected Works of Deng Xiaoping (Volume 2). People's Publishing House, Beijing, 332. 